\title{
AMICUS CURIAE SEBAGAI BENTUK PERAN SERTA LEMBAGA SWADAYA MASYARAKAT DALAM PENEGAKAN HUKUM PIDANA LINGKUNGAN HIDUP
}

\author{
Ilma Aulia Nabila ${ }^{1}$, Elis Rusmiati2 ${ }^{2}$ Imamulhadi ${ }^{3}$ \\ ${ }^{1}$ Fakultas Hukum, Universitas Padjajaran, ilmanabila22@gmail.com \\ ${ }^{2}$ Fakultas Hukum, Universitas Padjajaran, \\ ${ }^{3}$ Fakultas Hukum, Universitas Padjajaran
}

\begin{abstract}
Environmental problems are collective problems that require the participation of all components of the nation, one of which includes environmental NGOs which have the right to participate in the protection and management of the environment, especially in the context of enforcing environmental criminal law. In practice, NGO participation can be a third party with an interest in pretrial, a witness or an expert in a trial or filing amicus curiae in environmental criminal cases. However, the role of environmental NGOs themselves is still a matter of debate by law enforcers because there is no place in the legislation which results in legal uncertainty for environmental NGOs to participate in environmental criminal law enforcement. This research is normative juridical. By using a descriptive analytical approach, this study aims to determine the extent of the role of environmental NGOs and the obstacles to manifesting the role of NGOs in the enforcement of environmental criminal law.
\end{abstract}

\section{ARTICLE INFO}

\section{Keywords:}

Enforcement of

environmental criminal law;

Non-Governmental

Organizations;

Participation; amicus curiae

\section{Cite this paper:}

Ilma Aulia Nabila, E. R. (2021). Amicus Curiae Sebagai Bentuk Peran Serta Lembaga Swadaya

Masyarakat Dalam Penegakan Hukum Pidana Lingkungan Hidup. Widya yuridika: Jurnal Hukum.

Scope Article

Environmental Law

\section{PENDAHULUAN}

Dewasa kini makin maraknya kerusakan lingkungan hidup dan memperparah kualitas lingkungan hidup yang menyebabkan perubahan iklim yang ekstrem dan dampak negatif bagi masyarakat. Maka dari itu, sudah sepatutnya dilakukan perlindungan dan pengelolaan lingkungan hidup agar bisa menjamin terpenuhinya hak asasi manusia untuk mendapatkan lingkungan yang baik dan sehat. Perlindungan dan pengelolaan lingkungan hidup yang merupakan tanggung jawab pemerintah dan masyarakat meliputi perencanaan, pemanfaatan, pengendalian, pemeliharaan, pengawasan, dan penegakan hukum ${ }^{1}$ untuk mencegah terjadinya pencemaran dan atau perusakan lingkungan hidup. Sebagai persoalan kolektif yang membutuhkan partisipasi semua komponen bangsa untuk melakukannya, partisipasi atau peran serta dari LSM Lingkungan Hidup menjadi salah satu hal yang penting

\footnotetext{
${ }^{1}$ Pasal 4 UU No. 32 Tahun 2009 tentang Perlindungan dan Pengelolaan Lingkungan Hidup.
} 
dalam persoalan lingkungan hidup. Hal ini sangat dibutuhkan mengingat pengelola lingkungan (pemerintah) biasanya dapat merumuskan persoalan biologis dan teknis secara efektif, namun tidak berhasil dalam mewujudkan aspek-aspek sosial dalam pengelolaan lingkungan hidup. Hal ini semata-mata sebagai perwujudan dari asas yang terdapat dalam Pasal 2 Undang-Undang Nomor 32 Tahun 2009 tentang Perlindungan dan Pengelolaan Lingkungan Hidup (selanjutnya disebut sebagai UU PPLH) yaitu asas partisipatif.

LSM diberikan akses untuk berperan serta dalam kegiatan yang menimbulkan dampak terhadap lingkungan hidup, salah satunya dalam konteks penegakan hukum sebagai salah satu bagian dari perlindungan dan pengelolaan lingkungan hidup. Namun, nyatanya penegakan hukum lingkungan masih sangat menonjolkan penegakan hukum administrasi yang bersifat preventif $^{2}$ daripada penegakan hukum lainnya, khususnya penegakan hukum pidana. Tentu saja hal tersebut tidak bisa menjamin apabila pencemaran dan atau kerusakan lingkungan hidup tersebut sudah terjadi sehingga mengakibatkan dampak negatif bagi masyarakat. Padahal sudah seharusnya apabila kita berbicara mengenai penegakan hukum lingkungan hidup, mencakup juga kepada keseluruhan aspek hukum yang terdapat pada UU PPLH sendiri, termasuk juga hukum Pidana. Sebagaimana kita ketahui, meskipun penegakan hukum pidana lingkungan hidup memperhatikan asas ultimum remedium, meskipun begitu bukan berarti peran serta masyarakat harus berhenti pada upaya penegakan hukum administrasi karena sudah sepatutnya peran serta masyarakat terus dilaksanakan sampai segala proses di seluruh lingkup peradilan.

Sejatinya, hukum lingkungan sudah mengadopsi banyak asas hukum untuk memberikan akses yang luas kepada masyarakat untuk bersifat responsif, partisipatif, dan aplikatif atas berbagai hak atas lingkungan hidup. Antara lain hak memperoleh lingkungan yang sehat dengan mekanisme konsep actively participatory bagi warga masyarakat dan LSM, yang kemudian melahirkan legal standing (kedudukan hukum). ${ }^{3}$

Adapun dipandang dari segi mekanisme penegakan hukum, apabila korban lingkungan mempergunakan mekanisme biasa, tentulah akan menghadapi banyak kesulitan untuk menuntut kompensasi dan atau pemulihan fasilitas lingkungan yang mengalami kerugian. Pola kerugian lingkungan selanjutnya mendorong sistem hukum untuk berkembang, yang pada pokoknya lebih mengakomodasikan kepentingan-kepentingan publik, baik dalam dimensi berkaitan dengan produk kebijakan publik pengambilan keputusan, kepentingan asset publik, kepentingan kompensasi (perdata) dan pemulihan lingkungan (environmental recovery), pertanggungjawaban pidana, governmental responsibility, dan sebagainya. ${ }^{4}$

Kerap kali dalam melaksanakan peran sertanya seperti memberikan laporan adanya dugaan tindak pidana lingkungan hidup atau dalam memperjuangkan hak atas lingkungan baik dan sehat, para individu yang tergabung dalam LSM yang melakukan aktivitas tersebut dipandang sebelah mata dan malah dilaporkan kembali atas tindak pidana lain seperti telah dianggap melakukan tindak pidana pencemaran nama baik atau tindak pidana lainnya di KUHP maupun di luar KUHP. Menurut data Wahana Lingkungan Hidup (selanjutnya disebut dengan WALHI) setidaknya terdapat 146 kasus kriminalisasi yang menyasar pejuang lingkungan hidup di Jawa dalam periode 2015-20195, hal ini tentu saja menjadi suatu perhatian karena setiap tahunnya kasus serupa terus meningkat secara signifikan padahal kembali mengingat bahwa amanat UU PPLH sendiri adalah peningkatan peran serta masyarakat demi terpenuhinya hak atas lingkungan yang baik dan sehat serta terwujudnya pembangunan berkelanjutan.

\footnotetext{
2 Imam Supardi, Lingkungan Hidup dan Kelestariannya, hlm. 35

${ }^{3}$ N.H.T Siahaan, Hukum Lingkungan, hlm. 198

${ }^{4}$ Nommy H.T. Siahaan, "Perkembangan Legal Standing Dalam Hukum Lingkungan (Suatu Analisis Yuridis Dalam Public Participatory Untuk Perlindungan Lingkungan)”, 8:11, JURNAL HUKUM: SYIAR HUKUM (2011), hlm. 74

${ }^{5}$ Nur Azizah, "Walhi Bicara Kasus Kriminalisasi Pejuang Lingkungan Hidup", https://news.detik.com/berita/d4816859/walhi-bicara-kasus-kriminalisasi-pejuang-lingkungan-hidup $>$ diakses pada tanggal 2 Februari 2020 pukul 16.30 WIB
} 
Peran serta masyarakat merupakan bagian penting dalam pengelolaan lingkungan hidup demi tercapainya pemenuhan hak atas lingkungan hidup yang mana salah satunya adalah kontrol masyarakat. Bentuk pengakuan terhadap kontrol oleh masyarakat dalam pengambilan keputusan/kebijakan salah satunya adalah Convention on Access to Information, Public Participation in Decision-making and Access to Justice in Environmental Matters atau yang dikenal sebagai konvensi Aarhaus. ${ }^{6}$ Lebih lanjut, fungsi peran serta masyarakat dalam pengelolaan lingkungan hidup menurut Koesnadi Hardjasoemantri memiliki jangkauan yang sangat luas, tidak hanya meliputi peran serta para individu yang terkena berbagai peraturan atau keputusan administratif, namun meliputi pula peran serta kelompok dan organisasi dalam masyarakat ${ }^{7}$.

Menurut Levinson yang dikutip oleh Soerjono Soekanto ${ }^{8}$, peranan paling sedikit mencakup 3 hal, yaitu:

1. Peran meliputi norma-norma yang berhubungan dengan posisi atau tempat seseorang dalam masyarakat.

2. Peranan adalah suatu konsep apa yang dilakukan oleh individu sebagai organisasi.

3. Peranan juga dapat dikatakan sebagai prikelakuan individu yang penting bagi struktur sosial dalam masyarakat.

Oleh karena itu, sebagai perwujudan faktor-faktor tersebut, LSM hadir sebagai bentuk komponen masyarakat yang memiliki peran penting dalam proses pengambilan keputusan dan penegakan hukum. Lebih lanjut, dalam kaitannya dengan peran serta masyarakat, Instruksi Menteri Dalam Negeri Nomor 8 Tahun 1990 tentang Pembinaan LSM, menjelaskan bahwa LSM adalah organisasi atau lembaga yang dibentuk oleh masyarakat secara sukarela atas kehendak sendiri dan berminat serta bergerak dalam bidang kegiatan tertentu yang ditetapkan oleh organisasi atau lembaga sebagai wujud partisipasi masyarakat dalam upaya meningkatkan taraf hidup dan kesejahteraan masyarakat, yang menitikberatkan kepada pengabdian secara swadaya.

UU PPLH memiliki ketentuan terkait hak-hak LSM yaitu salah satunya hak gugat Organisasi Lingkungan Hidup, namun adanya hal tersebut dirasa tidak cukup, keberadaan LSM demikian dibatasi hanya dari sudut administratif, padahal perlu diingat bahwa UU PPLH sendiri menerapkan tiga aspek hukum dalam penegakannya yang tidak hanya administrasi dan perdata namun adanya aspek hukum pidana. Ben Boer melihat sistem hukum lingkungan Indonesia sebagai sistem tertutup (closed legal standing), karena begitu terbatasnya pihak atau orang yang dapat berperan dalam hal terdapatnya perbuatanperbuatan yang merugikan. ${ }^{9}$

Pada dasarnya penegakan hukum haruslah memperhatikan tiga hal yaitu: kepastian hukum, kemanfaatan dan keadilan. Keadilan yang diciptakan oleh hakim dalam rangka penegakan hukum pidana merupakan suatu pilihan atau merupakan suatu kombinasi dengan mengutamakan kebenaran materil. ${ }^{10}$ Sebagaimana dalam proses peradilan pidana, hakim senantiasa berpedoman pada sistem pembuktian yang dianut di peradilan pidana Indonesia yang diatur dalam Pasal 183 KUHAP, yaitu sistem pembuktian negatif ${ }^{11}$ yang mana terdapat dua komponen di dalam sistem pembuktian ini untuk menentukan salah atau tidaknya seorang terdakwa, yaitu:

1. Pembuktian harus dilakukan menurut cara dan dengan alat-alat bukti yang sah menurut undang-undang; dan

2. Keyakinan hakim.

\footnotetext{
${ }^{6}$ The United Nations Economic Commission for Europe (UNECE), Convention on Access to Information, Public Participation in Decision-making and Access to Justice in Environmental Matters, disahkan pada 25 Juni 1998 di Aarhus, Denmark.

${ }^{7}$ Koesnadi Hardjasoemantri, Hukum Tata Lingkungan, hlm. 97

8 Soerjono Soekanto, Sosiologi Suatu Pengantar, hlm. 213

${ }^{9}$ Ben Boer, Environmental Law and Enforcement (Course Material), hlm. 11

${ }^{10}$ Sidik Surnaryo, Kapita Selekta Sistem Peradilan Pidana, hlm. 217

${ }^{11}$ Martiman Projohamidjojo, Komentar atas KUHAP: Kitab Undang-Undang Hukum Acara Pidana, hlm. 102
} 
Selain memperhatikan hal tersebut, hakim juga wajib menggali nilai-nilai yang ada di masyarakat dalam pertimbangannya mengenai putusan suatu perkara sebagaimana diamanatkan dalam Pasal 5 ayat (1) UU No. 48 Tahun 2009 tentang Kekuasaan Kehakiman. Mengingat dalam suatu sistem peradilan pidana yang bekerja secara objektif dan tidak memihak hal tersebut merupakan faktor penilai suatu penegakan hukum berjalan dengan baik. ${ }^{12}$ Teer Har menyatakan bahwa demi terciptanya keadilan dalam memutus suatu perkara, hakim Indonesia harus mendekatkan diri serapat-rapatnya dengan masyarakat, ${ }^{13}$ terlebih lagi pada perkara lingkungan hidup yang mana menjunjung tinggi asas partisipatif yang bertitik pangkal pada masyarakat. Sejatinya, hukum lingkungan sudah mengadopsi banyak asas hukum untuk memberikan akses yang luas kepada masyarakat untuk bersifat responsif, partisipatif, dan aplikatif atas berbagai hak atas lingkungan hidup. Antara lain hak memperoleh lingkungan yang sehat dengan mekanisme konsep actively participatory bagi warga masyarakat dan LSM, yang kemudian melahirkan legal standing (kedudukan hukum). ${ }^{14}$

Tujuan peran serta masyarakat dalam penegakan hukum pidana lingkungan hidup adalah untuk menghasilkan masukan dan persepsi yang berguna dari warga negara dan masyarakat yang berkepentingan (public interest) dalam rangka meningkatkan pengambilan keputusan lingkungan. Proses peran serta masyarakat harus bersifat terbuka untuk umum, peran serta masyarakat yang diwakili oleh organisasi lingkungan hidup akan mempengaruhi kredibilitas (accountability) badan yang bersangkutan ${ }^{15}$.

Pada prakteknya dalam penegakan hukum pidana lingkungan hidup kerap kali LSM Lingkungan melakukan peran sertanya yang berupa pengajuan amicus curiae ke pengadilan sebagai dokumen guna membantu majelis hakim membuka pandangan dari sisi lingkungan hidup dan masyarakat itu sendiri, namun keberadaan bentuk peran serta LSM Lingkungan berupa amicus curiae keberadaannya masih menjadi hal yang memicu perbedaan pendapat diantara para penegak hukum, karena belum adanya aturan mengenai amicus curiae tersebut di hukum nasional meskipun di beberapa kasus lingkungan hidup sudah cukup banyak LSM mengajukan amicus curiae-nya. Selain bentuk peran serta berupa amicus curiae, LSM Lingkungan juga kerap kali menjadi pihak ketiga yang berkepentingan dalam praperadilan, dan menjadi saksi di persidangan.

Selanjutnya, berkaitan dengan teori-teori yang diuraikan di atas berdasarkan latar belakang tersebut di atas, peneliti ingin meneliti mengenai bentuk-bentuk peran serta Lembaga Swadaya Masyarakat dalam penegakan hukum pidana lingkungan hidup serta hambatan-hambatan yang terjadi dalam upaya perwujudannya.

Adapun manfaat dan tujuan dilakukannya penelitian ini adalah mengkaji dan mengetahui sejauh mana bentuk-bentuk peran serta LSM dalam penegakan hukum pidana lingkungan hidup dan apa saja hambatan-hambatan dalam upaya perwujudan dari peran serta LSM dalam penegakan hukum pidana lingkungan hidup itu sendiri.

\section{METODE}

Metode penulisan yang digunakan pada penelitian ini adalah yuridis normatif dengan spesifikasi penelitian menggunakan deskripstif analitis yaitu penggambaran secara lengkap atas suatu keadaan guna memperoleh data mengenai hubungan antar gejala ${ }^{16}$ dan menganalisis keterkaitannya dengan peraturan perundang-undangan. Dengan pengambilan data diperoleh dari studi kepustakaan (library research) dan studi lapangan berupa

\footnotetext{
12 Romli Atmasasmita, Sistem Peradilan Pidana Kontemporer, hlm. 6

${ }^{13}$ Andi Hamzah, Hukum Acara Pidana Indonesia, hlm. 104

14 N.H.T Siahaan, Hukum Lingkungan, hlm. 198

15 Lalu Sabardi, "Peran Serta Masyarakat dalam Pengelolaan Lingkungan Hidup menurut Undang-Undang Nomor 32 Tahun 2009 tentang Perlindungan dan Pengelolaan Lingkungan Hidup”, Journal Yustisia, 3:1, hlm. 74,2014

${ }^{16}$ Soerjono Soekanto, Pengantar Penelitian Hukum, hlm, 96
} 
wawancara. Data penelitian berupa bahan hukum primer, bahan hukum sekunder, dan bahan hukum tersier yang dianalisis secara kualitatif.

\section{HASIL DAN PEMBAHASAN}

\section{A. Implementasi Dan Bentuk Peran Serta LSM Dalam Penegakan Hukum Pidana Lingkungan Hidup}

Filosofinya bahwa lingkungan hidup membutuhkan semacam "wali" atau guardian yang mengurusi kepentingannya. Jika kepentingan lingkungan hidup itu terganggu, maka walinya itu yang akan bertindak, termasuk beracara di muka pengadilan. ${ }^{17}$ Salah satu pihak yang diharapkan dapat berperan serta dalam upaya penegakan hukum lingkungan di tengah kondisi masih terdapatnya berbagai kekosongan hukum lingkungan tersebut ialah Lembaga Swadaya Masyarakat (LSM). Kecakapan Lemabga Swadaya Masyarakat (LSM) tampil di muka pengadilan didasarkan pada suatu asumsi bahwa LSM sebagai "wali" (guardian) dari lingkungan. Pendapat ini berangkat dari teori yang dikemukakan oleh Christoper D. Stone dalam artikelnya yang dikenal luas di Amerika Utara yang berjudul Should Trees Have Standing? Toward Legal Rights for Natural Objects. Teori ini memberikan hak hukum (legal right) kepada objek-objek alam (natural objects). Menurut Stone, hutan, laut, atau sungai sebagai objek alam layak memiliki hak hukum dan adalah tidak bijaksana jika dianggap sebaliknya hanya dikarenakan sifatnya yang inanimatif (tidak dapat berbicara).

LSM Lingkungan Hidup dalam UU PPLH memiliki hak-haknya sebagai organisasi lingkungan yaitu salah satunya adalah hak ius standi yaitu hak atau kualitas untuk tampil dan bertindak sebagai pihak yang berhak berperan serta dalam hukum di pengadilan (persona standi in judicio) bagi organisasi lingkungan hidup untuk kepentingan pelestarian fungsi lingkungan hidup. ${ }^{18}$ UU PPLH sendiri telah mensyaratkan bahwa LSM/Organisasi lingkungan hidup memiliki hak gugat dalam rangka pelaksanaan tanggung jawab perlindungan dan pengelolaan lingkungan hidup, organisasi lingkungan hidup berhak mengajukan gugatan untuk kepentingan pelestarian fungsi lingkungan hidup. ${ }^{19}$ Sesuai dengan Pasal 92 ayat (3) UU PPLH, tidak semua LSM lingkungan hidup dapat mewakili lingkungan hidup dan masyarakat dalam penegakan hukum. Syarat LSM dapat mewakili masyarakat/lingkungan hidup adalah, sebagai berikut:

1. Berbadan hukum, karena tidak semua LSM merupakan badan hukum, di Indonesia sendiri LSM biasanya berbentuk Yayasan ${ }^{20}$ namun tidak sedikit juga LSM/Organisasi Lingkungan Hidup yang hanya berupa "perkumpulan" saja.

2. Anggaran dasarnya menjelaskan bahwa didirikan untuk kepentingan pelestarian fungsi lingkungan hidup. Hal ini dikenal dengan prinsip environmental oriented statue, yakni dalam anggaran dasarnya (statute) secara tegas menyebut tujuan pendirian organisasi adalah kepentingan pelestarian fungsi lingkungan hidup.

3. Melakukan kegiatan sesuai anggaran dasar minimal 2 (dua) tahun. Hal ini dikenal dengan actively environmental statute yakni telah melakukan kegiatan sesuai anggaran dasarnya. Kegiatan-kegiatan tersebut tidak dibatasi harus berupa satu kegiatan namun beberapa kegiatan yang memang didasarkan kepada kepentingan perlindungan dan pengelolaan lingkungan hidup.

Selain itu, terdapat banyak LSM Lingkungan Hidup di Indonesia yang memiliki kriteria seperti yang disebutkan di atas yang memiliki fokus berbeda-beda dalam rangka penegakan hukum lingkungan hidup seperti, antara lain: ${ }^{21}$

1. Aspek Kebijakan dan Riset;

\footnotetext{
17 Mas Achmad Santosa, Good Governance \& Hukum Lingkungan, hlm. 286-289

18 Moh Fadli, Mukhlis, Mustafa, Hukum dan Kebijakan Lingkungan Hidup, hlm. 103

${ }^{19}$ Lihat Pasal 92 ayat (1) UU PPLH

${ }^{20}$ Lihat Pasal 1 angka 1 UU No. 16 Tahun 2001 tentang Yayasan, Yayasan adalah badan hukum yang terdiri atas kekayaan yang dipisahkan dan diperuntukkan untuk mencapai tujuan tertentu di bidang sosial, keagamaan, dan kemanusiaan.

${ }^{21}$ Hasil diskusi dengan Peneliti Indonesian Center for Environmental Law (ICEL) pada 22 September 2020
} 
2. Melakukan investigasi dan mencari fakta-fakta dan bukti dalam perkara lingkungan hidup;

3. Primordial Grassroots;

4. Pendampingan Masyarakat dan Kajian yang berisi ahli-ahli.

Peran Serta LSM dalam penegakan hukum pidana lingkungan hidup sejatinya telah banyak dipraktekan dalam peradilan, misalnya LSM Lingkungan Hidup seperti WALHI , yang aktif mengajukan amicus curiae secara tertulis ke pengadilan dalam beberapa perkara pidana lingkungan hidup maupun perkara SLAPP (Strategic Lawsuit Against Public Participation) sebagaimana diatur dalam Pasal 66 UU PPLH selain itu bentuk peran serta LSM Lingkungan Hidup juga meliputi beberapa tahap dalam penegakan hukum pidana yaitu menjadi pihak ketiga yang berkepentingan dalam praperadilan, sebagai pelapor dan saksi tindak pidana lingkungan hidup.

WALHI sebagai salah satu organisasi/LSM Lingkungan Hidup yang berfokus kepada pendampingan masyarakat dan lingkungan hidup di dalam maupun di luar pengadilan memiliki legal standing untuk berperan serta dalam penegakan hukum lingkungan. WALHI sebagai LSM Lingkungan dalam legal standing sebagai penggugat atau tergugat mewakili kepentingan lingkungan hidup adalah nomeklatur sebagai pihak yang berperkara. WALHI dalam hal ini salah satu yang dapat mewakili masyarakat dan lingkungan di pengadilan sebagai penggugat dalam lingkup hukum perdata dan hukum. WALHI Jawa Barat yang merupakan salah satu cabang dari WALHI Nasional, sepanjang tahun 2015-2020, kerap kali melakukan pendampingan terhadap masyarakat maupun lingkungan paling banyak dalam perkara kebakaran hutan dan permasalahan izin lingkungan. WALHI Jawa Barat lebih terbilang jarang menggunakan legal standing-nya sebagai organisasi lingkungan hidup untuk berkedudukan sebagai penggugat, namun lebih kepada advokasi kepada masyarakat dan pendampingan selama proses penegakan hukum dan oleh karena WALHI Jawa Barat tidak dapat beracara langsung sebagai kuasa hukum atau penasihat dalam penegakan hukum lingkungan hidup maka WALHI Jawa Barat kerap kali bekerja sama dengan LBH Bandung untuk melakukan pendampingan. ${ }^{22}$

Dari berbagai bentuk peran serta LSM Lingkungan Hidup dalam Penegakan Hukum Pidana Lingkungan Hidup sejatinya yang paling cocok pada saat ini dalam rangka perlindungan dan pengelolaan lingkungan hidup masih memerlukan penelitian yang mendalam tentang berbagai aspek yang menyangkut pola sistem nilai masyarakat yang berkaitan dengan adat istiadat, aspirasi dan persepsi masyarakat sendiri. WALHI kerap kali memiliki kedudukan yang menempatkan WALHI sebagai LSM Lingkungan yang dapat langsung mewakili kepentingan yang berhubungan dengan lingkungan hidup secara langsung.

\section{LSM Lingkungan sebagai Amicus Curiae dalam Perkara Pidana Lingkungan Hidup.}

Dalam tradisi Common Law, mengenai amicus curiae secara luas tercatat dalam All England Report. Sebagaimana kita ketahui bahwa Indonesia sendiri dalam perkembangannya cenderung menganut mixed type (campuran) dalam sistem peradilan pidana Indonesia, ${ }^{23}$ Adapun gambaran berkaitan dengan Amicus Curiae di Indonesia adalah cara dimana pengadilan diberikan izin untuk mengundang pihak ketiga yang memiliki kepentingan atau kepedulan atas perkara itu atau atas prakarsa sendiri untuk membantu pengadilan guna menyediakan informasi atau fakta-fakta hukum berkaitan dengan isu-isu yang belum familiar. ${ }^{24}$ Amicus curiae ini kerap kali diajukan dalam tahap pengadilan, secara lisan maupun tulisan (yang selanjutnya disebut sebagai amicus brief). Amicus brief merupakan salah satu cara pengajuan amicus curiae yang biasanya dilakukan oleh LSM ke pengadilan, bahkan ketika

\footnotetext{
${ }^{22}$ Hasil diskusi dengan Deputi WALHI Jawa Barat pada tanggal 10 September 2020

23 Romli Atmasasmita, Sistem Peradilan Pidana Kontemporer, hal. 42

24 Refki Saputra, "Refleksi Peran Kantor Penghubung Komisi Yudisial dan Partisipasi Masyarakat dalam

Pengawasan Peradilan di Indonesia”, Jurnal Peradilan Indonesia Teropong, Vol. 6, 2017, hlm. 17
} 
pengadilan tersebut tidak mengadopsi mekanisme formal untuk menerima praktek tersebut atau disebut juga sebagai pengajuan non formal. ${ }^{25}$ Steven Kochevar mendefinisikan amicus curiae menggunakan dua kriteria utama yaitu: ${ }^{26}$

1. Dokumen yang secara sukarela disampaikan ke pengadilan oleh pihak selain pihak yang berperkara; dan

2. Keberadaannya tidak meniadakan diskresi dari pengadilan atas berkas yang disampaikan.

Dengan kata lain konsep amicus curiae di peradilan pidana di Indonesia secara limitatif hanya dilakukan dengan cara informal terhadap pemberian pendapat ke pengadilan.

WALHI sebagai LSM Lingkungan Hidup kerap kali mengajukan amicus curiae yang bertujuan untuk membantu hakim dalam memutuskan suatu perkara, hal ini berdasarkan pada Pasal 5 ayat (1) Undang-Undang Nomor 48 Tahun 2009 tentang Kekuasaan Kehakiman yang menyatakan:

"Hakim dan hakim konstitusi wajib menggali, mengikuti dan memahami nilainilai hukum dan rasa keadilan yang hidup dalam masyarakat"

Namun dalam keefektivitasannya, pengajuan amicus curiae ditentukan oleh jaminan kebebasan atau kemandirian pengadilan dan proaktifisme hakim dan prinsip pembuktian dalam suatu perkara yang khususnya dalam hal ini adalah perkara pidana lingkungan hidup. Lebih lanjut dalam prakteknya, majelis hakim dalam perkara pidana lingkungan hidup mempersamakan praktek amicus curiae ini dengan ahli dimana LSM Lingkungkungan Hidup dapat dihadirkan sebagai ahli oleh Penuntut Umum, Penasihat Hukum maupun Hakim di persidangan yang sifatnya kasuistis. Artinya, dalam pengajuan amicus curiae dipandang oleh hakim apabila suatu perkara tersebut sifatnya kasuistis. Kualifikasi ahli sejatinya memiliki keahlian khusus sebagaimana diatur dalam Pasal 1 angka 28 disebutkan bahwa:

"keterangan ahli adalah keterangan yang diberikan oleh seorang ahli yang memiliki keahlian khusus tentang hal yang diperlukan untuk membuat terang suatu perkara pidana guna kepentingan pemeriksaan"

Ahli sejatinya bukan saja memiliki keahlian khusus dengan Pendidikan formal yang sesuai bidang agar menjadi ahli namun ahli dalam Pendidikan non-fomal. Namun berbeda dalam prakteknya, beberapa kali WALHI dan ICEL sebagai LSM Lingkungan Hidup bekerjasama dengan ahli-ahli berkaitan perkara pidana lingkungan hidup. Namun ahli tetap hadir dengan nama pribadinya dalam persidangan dan tidak dinaungi oleh WALHI ataupun LSM Lingkungan lainnya.

\section{WALHI sebagai pihak yang berkepentingan dalam Praperadilan.}

Pasal 77 huruf a dan b KUHAP dan Pasal 95 KUHAP menjelaskan mengenai ruang lingkup praperadilan yaitu sebagai berikut:

a) Memeriksa dan memutus sah atau tidaknya penangkapan dan penahan;

b) Memeriksa dan memutus sah atau tidaknya penghentian penyidikan atau penghentian penuntutan;

c) Memeriksa dan memutus ganti kerugian dan atau rehabilitasi bagi seorang yang perkara pidananya dihentikan pada tingkat penyidikan atau penuntutan;

d) Memeriksa dan memutus terhadap tuntutan ganti kerugian yang diajukan oleh tersangka atau ahli warisnya atas penangkapan atau penahanan serta tindakan lain tanpa alasan yang berdasarkan undang-undang atau karena kekeliruan mengenai orang atau hukum yang diterapkan;

e) Memeriksa dan memutus permintaan rehabilitasi yang diajukan oleh tersangka atas penangkapan atau penahanan tanpa alasan berdasarkan

25 Steven Kochevar, "Amici Curiae in Civil Law Jurisdiction", The Yale Law Journal, Vol. 122, hlm. 1663, 2013

26 Steven Kochevar, op.cit, 1659 
undang-undang atau kekeliruan mengenai orang atau hukum yang diterapkan, yang perkaranya tidak diajukan ke Pengadilan Negeri.

Pihak yang dapat mengajukan Praperadilan selanjutnya diatur dalam Pasal 79 sampai Pasal 81 KUHAP.

Adapun dasar WALHI dapat mengajukan permohonan praperadilan adalah: ${ }^{27}$

1. Bahwa berdasarkan fakta bahwa Pemohon adalah badan hukum yang didirikan untuk kepentingan umum (public interest advocacy);

2. Bahwa berdasarkan Putusan Mahkamah Konstitusi dalam Perkara Nomor 76/PUU-X/2012 tertanggal 8 Januari 2013 yang pada intinya menyatakan bahwa pihak ketiga dalam pasal 80 Kitab Undang-undang Hukum Acara Pidana tidak hanya terbatas pada saksi dan korban tindak pidana tetapi juga di interpretasikan lebih luas;

3. Merujuk pada Putusan Mahkamah Konstitusi dalam tafsir pihak ketiga, tersebut Mahkamah Konstitusi menyatakan organisasi masyarakat atau lembaga swadaya masyarakat (LSM) yang memiliki kepentingan dan tujuan yang sama untuk memperjuangkan kepentingan umum (public interest advocacy);

\section{LSM Lingkungan sebagai Saksi dalam Perkara Pidana Lingkungan Hidup.}

Pembuktian dalam kasus lingkungan karena terjadinya pencemaran seringkali ditandai oleh sifat-sifat khas, antara lain:28

1) Penyebab tidak selalu dari sumber tunggal, akan tetapi berasal dari berbagai sumber (multiresources);

2) Melibatkan disiplin ilmu lainnya serta menuntut keterlibatan pakar-pakar di luar hukum sebagai saksi;

3) Akibat yang ditimbulkan seringkali tidak timbul seketika, akan tetapi berselang beberapa lama kemudian (long period of latency).

WALHI sebagai LSM Lingkungan Hidup yang berfokus pada advokasi dan pendampingan dalam perkara lingkungan hidup, kerap kali menjadi pihak yang dicari lebih awal oleh warga masyarakat yang terkena dampak kerusakan lingkungan hidup. WALHI yang juga dapat turut serta melakukan investigasi kerusakan lingkungan hidup lalu kerap kali WALHI setelah mendapatkan investigasi tersebut diteruskan pada Kepolisian untuk dilakukan pelaporan atas dugaan tindak pidana lingkungan hidup tersebut.

Sebagaimana yang ditegaskan dalam Pasal 96 UU PPLH bahwa alat bukti yang sah dalam tuntutan tindak pidana lingkungan hidup terdiri atas keterangan saksi; keterangan ahli; surat; petunjuk; keterangan terdakwa dan/atau alat bukti lain termasuk alat bukti yang diatur dalam peraturan perundang-undangan. Sehingga, apabila ditinjau dari segi nilai dan kekuatan pembuktian atau the degree of evidence, keterangan saksi dikatakan sah apabila salah satunya keterangan saksi memenuhi kualifikasi saksi dalam Pasal 1 angka 27 KUHAP, yaitu yang melihat, mendengar dan mengalami sendiri suatu peristiwa itu. Apabila dikaitkan dengan peran WALHI dalam pelaporan dugaan tindak pidana lingkungan hidup tersebut, maka WALHI dapat dikatakan memenuhi kualifikasi sebagai saksi dalam persidangan perkara pidana lingkungan hidup. Biasanya, WALHI sebagai saksi di persidangan diwakili oleh perorangan yang merupakan anggota WALHI sendiri. ${ }^{29}$

Pada akhirnya, penegakan hukum pidana harus pula mengacu pada nilai-nilai yang tumbuh dan berkembang di masyarakat demi tegaknya hukum itu sendiri, Keputusan Mahkamah Agung Nomor 026/KMA/SK/II/2013 tentang Sistem Seleksi dan Pengangkatan Hakim Lingkungan Hidup. Dijelaskan lebih lanjut bahwa hakim lingkungan hidup haruslah

${ }^{27}$ Hasil diskusi dengan Direktur Eksekutif WALHI Jawa Barat pada tanggal 10 September 2020.

${ }^{28}$ Mas Achmad Santosa, op.cit, hlm. 296

${ }^{29}$ Hasil diskusi dengan Manajer Kebijakan WALHI Nasional pada tanggal 12 Oktober 2020. 
memiliki kompetensi yang berbeda dari hakim lainnya salah satunya adalah judicial activism yaitu serangkaian pengetahuan, keterampilan dan ciri kepribadian yang mendukung dan mendorong hakim untuk dapat menemukan dan menggali nilai-nilai hukum terkait lingkungan hidup tidak tertulis yang hidup dan local wisdom di masyarakat sesuai dengan prinsip dan aturan hukum. Bahwa dengan adanya amicus curiae yang diajukan dalam perkara lingkungan hidup khususnya hukum pidana membantu hakim dalam menunjang keterampilan tersebut dalam memutuskan suatu perkara. Maka dari itu, kembali kepada tujuan dari peran serta dalam penegakan hukum pidana lingkungan hidup itu sendiri yaitu menghasilkan masukan dan persepsi yang berguna bagi warga negara dan masyarakat yang berkepentingan (public interest) sebagaimana asas keseimbangan yang dianut oleh KUHAP itu sendiri. Penegakan hukum lingkungan pidana dilaksanakan melalaui sistem peradilan pidana lingkungan secara terpadu (integrated environment criminal justice system), yaitu dimulai tahap penyidikan, penuntutan perkara, pemeriksaan perkara, serta putusan dan eksekusi. Dengan demikian, penegakan hukum lingkungan pidana harus dilaksanakan melalui jalur litigasi dan selamanya tidak mungkin dilaksanakan dengan cara lain, seperti musyawarah atau perundingan, sebagaimana pendapat Muladi mengenai sistem peradilan pidana yang merupakan suatu jaringan (network) peradilan yang menggunakan hukum pidana materil, hukum pidana formil maupun pelaksanaan hukum pidana. Namun demikian kelembagaan substansial ini harus dilihat dalam kerangka atau konteks sosial. Sifatnya yang terlalu dornal apabila dilandasi hanya untuk kepentingan kepastian hukum saja akan membawa kepada ketidakadilan. ${ }^{30}$ Sehingga, sejatinya sistem peradilan pidana perlu dipandang bukanlah merupakan hal yang harus dipertuan oleh masyarakat, namun keduanya perlu dipandang sebagai pelayan untuk masyarakat.

Soerjono Soekanto memaparkan mengenai faktor-faktor penegakan hukum yaitu: faktor hukum; faktor penegak hukum; faktor sarana pendukung; faktor masyarakat; faktor kebudayaan. Salah satu dari faktor tersebut sebagaimana disebutkan di atas adalah faktor masyarakat, Masyarakat yang menentukan suatu hukum berlaku di suatu lingkup kehidupan bermasyarakat karena peraturan dibuat semata-mata untuk melindungi hak dan kewajiban masyarakat. Peran serta LSM Lingkungan Hidup sendiri ada di dalam hampir seluruh fator yang mempengaruhi penegakan hukum, yaitu terdapat dalam faktor sarana atau fasilitas, faktor masyarakat dan faktor kebudayaan.

\section{B. Hambatan Dalam Upaya Perwujudan Peran Serta LSM Dalam Penegakan Hukum Pidana Lingkungan Hidup.}

\section{Hambatan Internal}

Hambatan Internal merupakan hambatan yang berasal dari dalam LSM Lingkungan Hidup itu sendiri. Hambatan internal ini yang dapat membuat masyarakat terlebih anggota LSM Lingkungan Hidup sulit untuk maju dan berperan khususnya dalam penegakan hukum pidana lingkungan hidup. WALHI Jawa Barat ${ }^{31}$ menyatakan bahwa hambatan internal yang dihadapi khususnya dalam WALHI Jawa Barat adalah tidak adanya Sumber Daya Manusia yang dapat mewakili langsung sebagai Penasihat Hukum/Kuasa Hukum dalam penyelesaian perkara lingkungan hidup. Sehingga, WALHI Jawa Barat jarang sekali menggunakan legal standing-nya di pengadilan, sehingga untuk WALHI Jawa Barat bekerjasama dengan LBH Bandung sebagai penasihat hukum/kuasa hukum yang mewakili di pengadilan.

Selain itu, hambatan internal lainnya WALHI Jawa Barat adalah kurangnya pendanaan, hal tersebut dikarenakan WALHI sendiri merupakan organisasi lingkungan hidup independent non-profit yang sistem pendanaannya berasa dari uang anggota, sumbangan masyarakat individu serta Lembaga dana lainnya baik nasional maupun internasional, namun hal itu tidak menjamin dana kas yang masuk ke WALHI tiap wilayah memadai,

30 Muladi, Kapita Selekta Sistem Peradilan Pidana, hlm. 18

${ }^{31}$ Hasil diskusi dengan Direktur Eksekutif WALHI Jawa Barat pada tanggal 9 Oktober 2020 
sedangkan menurutnya untuk melanjutkan perkara ke persidangan membutuhkan dana yang tidak sedikit.

\section{Hambatan Eksternal}

Adapun hambatan eksternal yang dihadapi oleh WALHI dalam upaya perwujudan peran sertanya, adalah sebagai berikut:

a. Kurangnya perlindungan bagi para pelapor dan aktivis lingkungan hidup.

Perlindungan bagi para aktivis lingkungan hidup yang sedang melakukan advokasi dan demokrasi demi membela kepentingan lingkungan hidup kerap kali malah dikriminalisasi dan dilaporkan balik atas tuduhan lain, banyak diantaranya dilaporkan dengan tuduhan pencemaran nama baik atau dituduh melakukan Tindakan illegal dalam pemanfaatan lahan/tanah yang biasanya diklaim milik suatu perusahaan. Padahal jelas dalam UU PPLH telah diatur mengenai Anti-SLAPP (Strategic Lawsuit Against Public Participation) yang ditegaskan dalam SK KMA No. 036/KMA/SK/II/2013 dimana dijelaskan bahwa Anti SLAPP merupakan perlindungan hukum bagi pejuang lingkungan hidup, gugatan SLAPP dapat berupa gugatan balik (gugatan rekonvensi), gugatan biasa atau berupa pelaporan telah melakukan tindak pidana bagi pejuang lingkungan hidup (misalnya, dianggap telah melakukan perbuatan "penghinaan" sebagaimana diatur dalam KUHP). Namun salah satu alasan tidak terlaksananya amanat dari Pasal 66 UU PPLH adalah tidak adanya peraturan pelaksana dari ketentuan tersebut yang mengakibatkan masih terdapat pengabaian dan ketidakpastian hukum yang ditimbulkan oleh aparat penegak hukum.

b. Kurang responsifnya aparat penegak hukum

Selama ini peran serta WALHI sebagai LSM Lingkungan Hidup dalam rangka penegakan hukum lingkungan hidup sudah cukup efektif dan cukup banyak inisiatif akan hal itu. Namun yang membuat masyarakat dan anggota LSM Lingkungan yang lain merasa kurang mendapat respon baik dari penegak hukum dengan melakukan peran sertanya memberikan informasi dan laporan kepada penegak hukum adalah keterlambatan respon dari aparat penegak hukum..$^{32}$

\section{PENUTUP}

Kedudukan dari LSM Lingkungan Hidup dalam penegakan hukum pidana lingkungan hidup sejatinya diakui dalam setiap proses penegakan hukum pidana dimulai dari tahap pelaporan hingga putusan pengadilan dalam kapasitasnya menjadi pihak yang dapat melakukan investigasi dalam hal adanya dugaan tindak pidana lingkungan hidup, menjadi pihak ketiga yang berkepentingan dalam Praperadilan, saksi dan kerap kali mengajukan amicus curiae guna membantu hakim dalam memutus perkara dari sudut pandang kepentingan lingkungan hidup dan masyarakat. Namun secara yuridis, belum ada peraturan yang mengatur secara jelas mengenai bentuk peran serta LSM Lingkungan Hidup khususnya dalam Penegakan Hukum Pidana Lingkungan Hidup, padahal dalam prakteknya LSM Lingkungan Hidup seperti WALHI memiliki legal standing yang perlu dipandang sebagai jalan masuk pada ranah litigasi yang sampai saat ini penggunaannya oleh WALHI sendiri terkhususnya WALHI Jawa Barat belum dapat dimanfaatkan secara maksimal.

Ketidakpastian hukum bagi peran serta LSM Lingkungan dalam penegakan hukum pidana lingkungan hidup menimbulkan beberapa hambatan, diantara lain adanya hambatan internal berupa tidak adanya SDM yang memiliki kapasitas untuk mewakili lingkungan hidup dalam proses peradilan, dan kurangnya pendanaan. Sedangkan hambatan eksternal yang dihadapi adalah kurangnya perlindungan bagi para pelapor dan aktivis lingkungan hidup dan kurangnya responsif dari penegak hukum karena perbedaan pandangan yang kerap kali menimbulkan keterlambatan proses penanganan perkara didasari oleh 
perbedaan pendapat antar penegak hukum mengenai peran serta LSM Lingkungan karena belum adanya aturan hukum yang mengaturnya.

\section{DAFTAR PUSTAKA}

Atmasasmita, Romli. 2010. Sistem Peradilan Pidana Kontemporer, Jakarta. Kencana.

Hamzah, Andi. 2010. Hukum Acara Pidana Indonesia. Jakarta: Sinar Grafika.

Boer, Ben. 2001. Environmental Law and Enforcement (Course Material), IASTP II, Cameron Sydney.

Hardjasoemantri, Koesnadi. 2005. Hukum Tata Lingkungan, Yogyakarta: Gadjahmada University Press.

Muladi. 1995. Kapita Selekta Sistem Peradilan Pidana, Semarang: UNDIP Press.

Moh Fadli dan Mukhlis, Mustafa. 2016. Hukum dan Kebijakan Lingkungan Hidup, Malang: UB Press.

Projohamidjojo, Martiman. 2010. Komentar atas KUHAP: Kitab Undang-Undang Hukum Acara Pidana, Jakarta: Pradnya Paramitha.

Santosa, Mas Achmad. 2001. Good Governance \& Hukum Lingkungan, Jakarta: ICEL.

Supardi, Imam. 2003. Lingkungan Hidup dan Kelestariannya. Bandung: Alumni.

Siahaan, N.H.T. 2007. Hukum Lingkungan, Jakarta: Pancuran Alam.

Soekanto, Soerjono. 1984. Pengantar Penelitian Hukum, Jakarta: UI Press.

Soekanto, Soerjono. 2010. Sosiologi Suatu Pengantar, Jakarta: PT Rajawali Pers.

Surnaryo, Sidik. 2004. Kapita Selekta Sistem Peradilan Pidana, Malang: UMM Press.

\section{Jurnal}

Saputra, Refki. "Refleksi Peran Kantor Penghubung Komisi Yudisial dan Partisipasi Masyarakat dalam Pengawasan Peradilan di Indonesia". Jurnal Peradilan Indonesia Teropong, Vol. 6. (Juli 2017) Retrieved from http://mappifhui.org/wpcontent/uploads/2018/02/Jurnal-Teropong-Vol-6-Juli-Desember-2017.pdf

Kochevar, Steven. "Amici Curiae in Civil Law Jurisdiction". The Yale Law Journal, Vol. 122. Retrieved

from https://digitalcommons.law.yale.edu/cgi/viewcontent.cgi?article=5563\&context= ylj

Nommy H.T. Siahaan, "Perkembangan Legal Standing Dalam Hukum Lingkungan (Suatu Analisis Yuridis Dalam Public Participatory Untuk Perlindungan Lingkungan)", Jurnal Hukum: Syiar Hukum (UNISBA) Vol. 13 No. 3 November 2011. Retrieved from https://ejournal.unisba.ac.id/index.php/syiar_hukum/article/view/662

Lalu Sabardi, "Peran Serta Masyarakat dalam Pengelolaan Lingkungan Hidup menurut Undang-Undang Nomor 32 Tahun 2009 tentang Perlindungan dan Pengelolaan Lingkungan Hidup", Journal Yustisia, 3:1, 2014. Retrieved from https://jurnal.uns.ac.id/yustisia/article/view/10120/9030

\section{Peraturan Perundang-Undangan}


The United Nations Economic Commission for Europe (UNECE), Convention on Access to Information, Public Participation in Decision-making and Access to Justice in Environmental Matters, disahkan pada 25 Juni 1998 di Aarhus, Denmark.

Undang-Undang Nomor 32 Tahun 2009 tentang Perlindungan dan Pengelolaan Lingkungan Hidup

Undang-Undang Nomor 48 Tahun 2009 tentang Kekuasaan Kehakiman.

\section{Naskah Internet}

Nur Azizah, "Walhi Bicara Kasus Kriminalisasi Pejuang Lingkungan Hidup", https://news.detik.com/berita/d-4816859/walhi-bicara-kasus-kriminalisasipejuang-lingkungan-hidup> diakses pada tanggal 2 Februari 2020 